\title{
Application of Rationale and Argumentation in Refuting Up-To-DATE MYTHS AND STEREOTYPES
}

\author{
UZASADNIANIE I ARGUMENTOWANIE \\ W KOMUNIKACJI Z OSOBAMI PODDANYMI MITOM \\ I STEREOTYPOM
}

\begin{abstract}
To characterize rationale and argumentation as subjects of scientific research. To represent application of rationale and argumentation technology in on-line discussions on the basis of selected examples.

Analysis and generalization of scientific sources and documents was performed. Practice of using rationale and argumentation in on-line discussions was analyzed.

The first discussion is an on-line dialog between a philosopher and an economist. The philosopher refutes the stereotypical position of his opponent consisting in denying importance of the humanities for the society and in the desire to achieve the abolition of funding for all humanitarian researches.

The second example concerns the selection of arguments for dispelling the mythological worldview formed by the means of the Russian information propaganda regarding the Russian-Ukrainian war.

In the age of information society, when information aggression is growing and increasingly turning into an information war, it is essential to be able to rationalize and argue own position as well as to unmask false statements. This skill is especially important in counteracting mythologization of the society and spread of stereotypes.
\end{abstract}




\section{STRESZCZENIE}

Celem artykułu jest scharakteryzowanie uzasadnienia i argumentacji jako przedmiotów badań naukowych, jak również zaprezentowanie zastosowania technologii uzasadnienia i argumentacji w dyskusjach online na podstawie wybranych przykładów.

Przeprowadzono analizę i uogólnienie źródeł naukowych i dokumentów. Przeanalizowano praktykę stosowania uzasadnienia i argumentacji w dyskusjach online.

Pierwsza dyskusja to internetowy dialog między filozofem a ekonomistą. Filozof obala stereotypowe stanowisko swojego przeciwnika, polegające na negowaniu znaczenia nauk humanistycznych dla społeczeństwa, zgodnie z którym należy dążyć do zniesienia finansowania wszystkich badań z dziedziny humanistyki.

Drugi przykład dotyczy wyboru argumentów do obalenia mitologicznego światopoglądu, utworzonego za pomocą rosyjskiej propagandy informacyjnej dotyczącej wojny rosyjsko-ukraińskiej.

W dobie społeczeństwa informacyjnego, gdy agresja informacyjna narasta i zamienia się w wojnę informacyjną, niezbędna jest umiejętność racjonalizacji i argumentowania na rzecz swojej racji, a także demaskowania fałszywych oświadczeń. Ta umiejętność jest szczególnie ważna dla przeciwdziałania mitologizacji społeczeństwa i rozpowszechnianiu stereotypów.

KEYWORDS: rationale, argumentation, discussion, convictions, disproof of stereotype, myth dispelling

SŁowA KLUCzowe: uzasadnianie, argumentowanie, dyskusja, przekonywanie, sprostowanie stereotypu, obalanie mitu

\section{WPROWADZENIE}

W dobie społeczeństwa informacyjnego, gdy - agresja informacyjna staje się coraz większa i coraz częściej przeobraża się w wojnę informacyjną - umiejętność argumentowania ma ogromne znaczenie. Wskazana umiejętność jest szczególnie ważna w przeciwdziałaniu mitologizacji i stereotypizacji społeczeństwa. Należy znać sposoby umiejętnego uzasadnienia słuszności swojej opinii i umieć zdemaskować fałszywe tezy i nieuczciwe dowody.

Działalnie na rzecz demistyfikacji wymaga umiejętności należytego uzasadniania, czyli wskazywania podstawy uznania za prawdziwe omawianych treści. Osoba dokonująca demistyfikacji nie tylko powinna być kompetentna w swojej dziedzinie - w warunkach wojen informacyjnych szczególnie ważna jest umiejętność przekonywania, że twierdzenia tej osoby są praw- 
dziwe, a poglądy słuszne. Kompetencja ta polega m.in. na umiejętnościach uzasadniania i argumentowania.

Z jednej strony sądy uznawane za prawdziwe mogą być uzasadnione bezpośrednimi doznaniami i oparte na doświadczeniu. $Z$ drugiej, mogą być uzasadnione pośrednio, czyli wywnioskowane z treści już poprzednio przyjętych za prawdziwe.

Teoria Richarda Petty’ego i Johna Cacioppo (Petty, Caccipo, 1986) głosi, że są dwie główne drogi przekonywania: 1) droga ośrodkowa (central route), polegająca na solidnych argumentach, opartych na istotnych faktach i liczbach, które skłaniają ludzi do myślenia o danym zagadnieniu; 2) droga obwodowa (peripheral route), która zamiast próbować uruchomić u danej osoby myślenie, polega na dostarczeniu sygnałów, które pobudzają do akceptacji argumentu bez większego namysłu (Aronson, 2001, s. 75).

\section{UZASADNIANIE}

Uzasadnianie jest rodzajem komunikacji interpersonalnej. Z jednej strony - to przepływ informacji w postaci przekazu i przetwarzania danych. Z drugiej natomiast uzasadnianie polega na przekonywaniu w postaci przedstawienia argumentacji i perswazji.

Schemat 1.

\section{Rusztowanie podstawowe - szkielet każdej dyskusji}

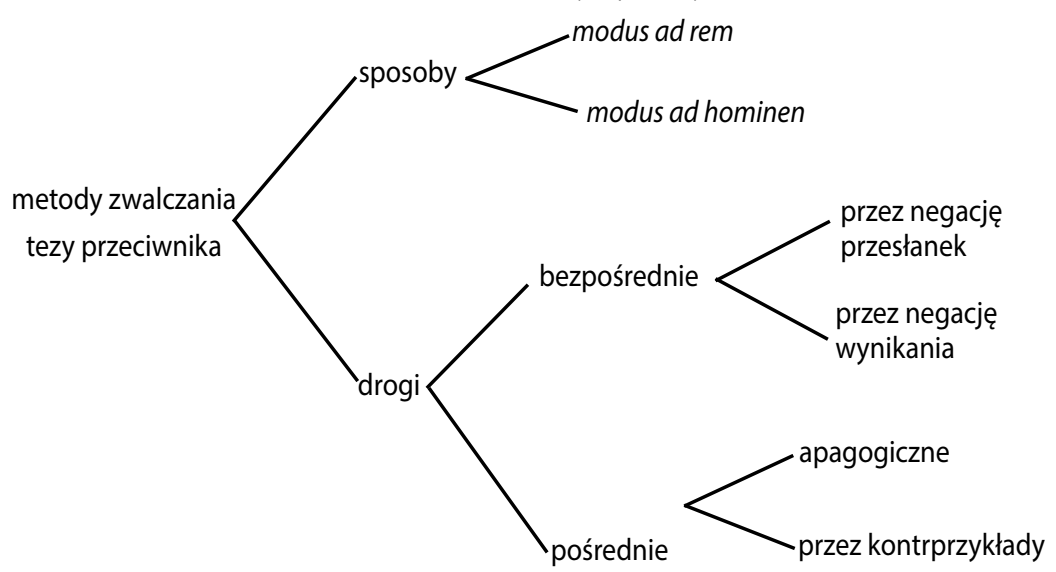

Źródło: A. Schopenhauer, Erystyka, czyli sztuka prowadzenia sporów (Nieznański, 2000, VI). 
Tradycyjnie uzasadniane są zdania, poglądy, decyzje. Podstawą uzasadniania jest to, że zdania mają być prawdziwe, a poglądy i decyzje - słuszne. Uzasadnianiem jest podawanie podstaw do uznania. W sytuacji gdy przytaczanie podstaw polega na odwołaniu się do faktów, jest to uzasadnianie bezpośrednie, a jeśli podstawami uznania nie są fakty, ale zdania uprzednio uznane - ten rodzaj uzasadniania nazywany rozumowaniem pośrednim (schemat 1; Nieznański, 2000, s. 114).

Sposoby obalenia tezy oponenta to: 1) wykazanie, „że twierdzenie nie zgadza się z naturą rzeczy”, czyli jest fałszywe (modus ad rem); 2) wykazanie „że nie zgadza się z innymi twierdzeniami przeciwnika lub założeniami, na które się on zgodził" (modus ad hominem) (Nieznański, 2000, VI).

Co do bezpośrednich dróg wykazania bezpodstawności lub błędności tezy oponenta, to „albo wykazujemy przeciwnikowi, że przesłanki jego twierdzenia są błędne; albo też akceptujemy przesłanki, wykazujemy jednak, że dane twierdzenie z nich nie wynika" (Nieznański, 2000, VI).

Pośrednie natomiast drogi obalania tezy przeciwnika opierają się na niezawodnej regule wnioskowania tollendo tollens: wykazując, że konsekwencją tezy przeciwnika jest fałsz, dowodzimy tym samym, że fałszywa jest sama jego teza. Jest to tzw. metoda apagogiczna, a gdy w niej teza jest zdaniem ogólnym, zaś konsekwencja - fałszywym zdaniem jednostkowym, staje się ona drogą per exemplum in contrarium, czyli drogą przez kontrprzykład (Nieznański, 2000, VI).

\section{Argumentowanie}

Argumentowanie to czynność zmierzająca do wywołania u kogoś określonych przeświadczeń lub ocen czy dążeń. Podczas argumentowania nadzwyczaj przydatną wiedzą jest wiedza logiczna, ponieważ w stosunku do człowieka rozsądnego najskuteczniejszym środkiem jest przeprowadzenie dowodu - wykazanie, że omawiana teza logicznie wynika ze zdań, które oponent gotów jest uważać za prawdziwe. W trakcie argumentowania osoba próbująca demistyfikować oponenta powinna korzystać nie tylko z zakresu logiki, ale „także z psychologii (jakimi motywami kierują się ludzie, decydując się na uznanie zdania za prawdziwe czy oceny za trafną), z socjologii (jak szeroko jest rozpowszechniony określony pogląd w społeczeństwie, kto go w danym społeczeństwie reprezentuje) i nauk zbliżonych" (zob. Ziembiński, 2006, s. 211). 
Schemat 2.

\section{Algorytm przekonywania}

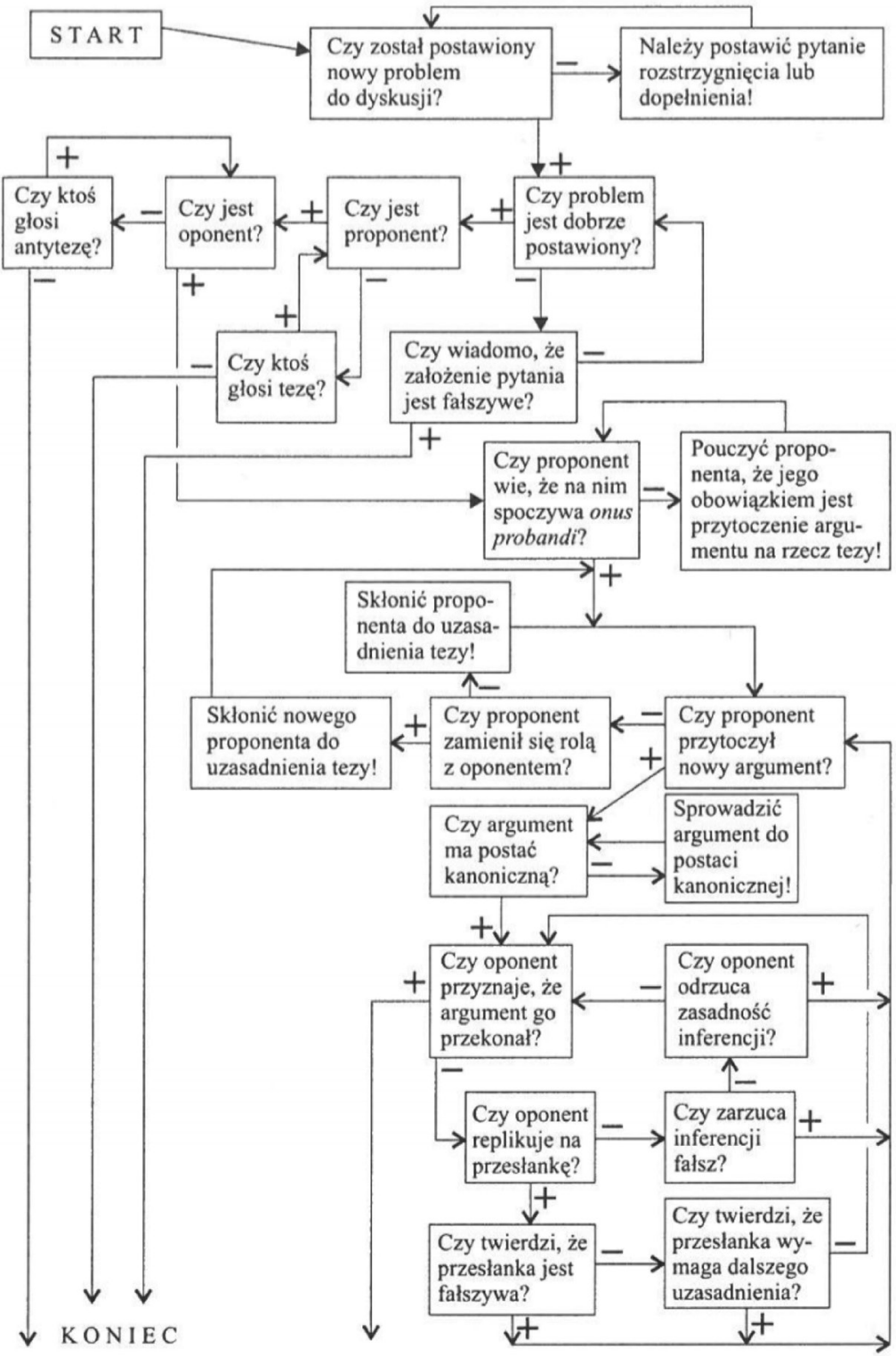

Źródło: (Nieznański, 2000, s. 117). 
Jak zauważa Zygmunt Ziembiński, spory w dyskusjach często polegają $\mathrm{z}$ jednej strony na spieraniu się o twierdzenia, $\mathrm{z}$ drugiej - na spieraniu się o oceny. Dlatego, mając na celu wywołanie u oponenta rzetelnie uzasadnionego przeświadczenia, iż proponowana przez nas teza jest prawdziwa i chcąc nakłonić kogoś do przyjęcia określonego sposobu oceniania pewnych zjawisk (czy do uznania pewnej normy za aksjologicznie uzasadnioną), należy pamiętać, że podstawą wyboru argumentacji jest rozumienie, czy przyczyną sporu jest różnica przeświadczeń, czy różnica ocen. Argumentacja w każdym z tych dwóch przypadków ma być inna (Ziembiński, 2006, s. 211). Algorytm przekonywania według Edwarda Nieznańskigo przedstawia schemat 2.

Mówiąc o mitach i stereotypach, można przyjąć, że spory o twierdzenia faktycznie są zetknięciem różnych mitologizowanych światopoglądów lub światopoglądu mitologicznego i realistycznego, a spory o oceny to zetknięcie sprzecznych ze sobą stereotypów lub stereotypów i rzeczywistości.

Stosowana w celu sprostowania stereotypu (tzn. w celu nakłonienia kogoś do przyjęcia określonego sposobu oceniania) argumentacja według Z. Ziembińskiego (Ziembiński, 2006, s. 212) ma:

- odwoływać się do ocen o ogólniejszym charakterze, których dana ocena jest efektem,

- wzbudzać postawy emocjonalne podobne do postaw argumentującego,

- uznawać za dobre czy złe konsekwencje faktu poddawanego ocenie, czyli uznawać tylko argumenty pragmatyczne.

\section{ZASTOSOWANIE LOGICZNEGO UZASADNIANIA W SPROSTOWANIU STEREOTYPU}

29 listopada 2019 r. filozof Aleksander Kulik na portalu społecznościowym Facebook zaproponował dyskusję na temat manipulacji dotyczących finansowania nauki. Post zawierał m.in. następujące informacje:

„Pewna grupa ludzi promuje tezę, że ukraińscy naukowcy z nauk przyrodniczych, ścisłych i technicznych mają niewielkie finansowanie państwowe, ponieważ fundusze, które powinny do nich należeć, państwo wydaje na naukowców humanistyki. A jeśli ukraińska humanistyka przestanie być finansowana - jej pieniądze zostaną podzielone między ukraińskich przedstawicieli nauk przyrodniczych, ścisłych i technicznych" (Kulik, 2019c). 
A. Kulik uważa takie rozważania za „dziecinne (czy bolszewickie?)”, naiwne i pyta swoich czytelników, jaki jest motyw zwolenników tej tezy: „przecież ci (dzięki Bogu, nieliczni, chociaż bardzo aktywni) przedstawiciele nauk przyrodniczych, ścisłych i technicznych nie mogą naprawdę w sposób tak uproszczony myśleć”. Jednak znany filozof uważa za oczywiste, że dla tych, którzy nie są zainteresowani poprawą stanu ukraińskiej nauki, najlepszym celem jest stworzenie sytuacji, w której naukowcy zaangażowaliby się w „polowania na czarownice” zamiast mówić o prawdziwych przyczynach istniejących problemów.

Temat zaproponowany przez Kulika wzbudził szerokie zainteresowanie i wiele komentarzy. Do dyskusji dołączyli także zwolennicy omawianej tezy. Jedna z tych osób zauważyła: „Proszę nie śmieszyć ludzi. O jaką humanistykę chodzi?”. Na komentarz oponentki autor postu odpowiedział:

„Pani zadała pytanie: «O jaką humanistykę chodzi?». Zacznijmy od prostych rzeczy. Dzięki historykom-humanistom Ukraińcy poznają historię swojego kraju. Czy jest to ważne? Czy jest to dla Pani «śmieszne» i nie uważa Pani to za konieczne? Dzięki filologom-humanistom Ukraińcy znają swój język. Czy jest to ważne? Czy jest to dla Pani też «śmieszne» i nie uważa Pani to za konieczne?" (Kulik, 2019b).

Oponentka, nie odpowiadając na pytanie Kulika, zmieniła temat dialogu: „Porozmawiajmy lepiej o filozofach, z których wielu jest plagiatorami”. Filozof jej odpowiedział:

„W swojej krótkiej odpowiedzi Pani użyła trzech manipulacji. Pierwsza to ignoratio elenchi, druga - to argumentum ad hominem, trzecia - to fallacia fictae universalitatis. Spójrzmy na to w kolejności.

Zacznijmy od Pani odejścia od tematu. W swoim początkowym pytaniu zakwestionowała Pani wszystkie nauki humanistyczne (to są Pani słowa: «Proszę nie rozśmieszać ludzi. O jaką humanistykę chodzi?»). Ale moją propozycję, aby zacząć od tego, co obala Pani tezę (przykład nauk humanistycznych, takich jak historia i filologia, w naukowość których nikt na świecie nie wątpi), Pani zignorowała i zamiast omawiać status nauk humanistycznych zaczęła Pani dyskutować o czymś innym.

Drugą Pani manipulacją jest argumentum ad hominem. Odpowiadając na Pani pytanie - celowo nie wziąłem pod uwagę dyscyplin, w które jeste- 
śmy zaangażowani - filozofii, jako nauki, którą ja reprezentuję i nauki, którą reprezentuje Pani - ekonomii. Ponieważ odciąga nas to od obiektywności. Natomiast Pani uciekła do tej metody sofistycznej.

Po trzecie, Pani manipulacja jest fałszywym uogólnieniem. Na przykładzie tego, że w wielu dysertacjach humanistycznych rzeczywiście występuje plagiat, nie można stwierdzić, że cała humanistyka jako taka nie jest nauką. Po pierwsze, nie wszyscy przedstawiciele nauk humanistycznych stosują plagiat. Po drugie, plagiat można znaleźć także w dysertacjach przedstawicieli innych dyscyplin naukowych.

Dopiero co mówiłem o Pani manipulacjach. Przejdźmy teraz do Pani oskarżeń. Pani krytykuje filozofów, że ich dysertacje są złej jakości. Spójrzmy na liczby. Oto dane z 2015 r. W tym roku obroniono dysertacje doktorskie: $\mathrm{z}$ nauk filozoficznych - 126, z nauk fizycznych i matematycznych - 271, z nauk biologicznych - 196, z nauk medycznych - 682, z nauk technicznych - 1113, z nauk ekonomicznych (które Pani reprezentuje) - 1191. Załóżmy, że część dysertacji z filozofii jest złej jakości. Ale jak to się wiąże z finansowaniem nauk przyrodniczych, nauk ścisłych i technicznych? Przypominam, że mój post głosi, że teza «humanistyki zabierają pieniądze od przyrodników», jest fałszywa. Załóżmy, że Pani osiągnęła swój cel i w Ukrainie wprowadzony zostanie zakaz obrony rozpraw filozoficznych. Czy te grosze, które zarabiają filozofowie, pozwolą przedstawicielom nauk przyrodniczych uzyskać lepszą pozycję w rankingach naukowych? Moralny aspekt kwestii «zabrać i podzielić» zostawiam na boku, ponieważ widzę, że dla Pani nie jest to ciekawe. Jednak same liczby mówią o tym, że Pani pozycja jest nie tylko destrukcyjna, ale także bezpodstawna" (Kulik, 2019a).

Oponentka stwierdziła, że posiada inne statystyki w sprawie rozpatrywania wniosków o plagiat i unieważnienia przez Ministerstwo Edukacji i Nauki decyzji wyspecjalizowanych rad ds. obrony dysertacji. Nie podała jednak żadnych konkretnych faktów i danych. Według niej osoby najbardziej narażone na popełnianie plagiatów to filozofowie. Wymieniła także jeden z uniwersytetów i stwierdziła, że jej zdaniem „przez pewien okres bez plagiatu nie została obroniona żadna rozprawa”. Według niej „pytanie nie dotyczy liczb ogólnych, ale dotyczy stopnia analizy dorobku osób zdobywających stopnie naukowe”. Dalej stwierdziła: „Temat, który Pan tu omawia, już dawno nie jest 
aktualny, ponieważ wartości społeczeństwa są skompromitowane, a zachowanie jest haniebne w zdecydowanej większości”. Na co A. Kulik, kontynuując dyskusję, zauważył:

„Znowu w Pani odpowiedzi są manipulacje. Tym razem: po pierwsze, a straw man fallacy, a po drugie, petitio principii.

Zaczęła Pani dyskusję od przypisania mi twierdzenia, którego nie wypowiedziałem. Nie powiedziałem ani słowa w obronie plagiatu. Ponadto w naszej dyskusji jasno i przejrzyście powiedziałem, że zdarzają się takie haniebne przypadki, dotyczące również filozofów. Prezentuje Pani sprawę w ten sposób, że Pani jest przeciw plagiatowi, a ja jestem za. To jest manipulacja a straw man fallacy.

Po drugie, napisała Pani: „ponieważ zachowanie jest haniebne w zdecydowanej większości”. To jest manipulacja petitio principii. Oznacza to, że jako potwierdzenie swojej tezy Pani przedstawia to, co samo wymaga potwierdzenia. Czym jest „zdecydowana większość”? Prawdopodobnie to ponad 70\%, rozważmy jednak lepszą dla Pani liczbę: $50 \%+1$. Jeśli twierdzi Pani, że większość ukraińskich filozofów stosuje plagiat, oznacza to, że ma Pani fakty potwierdzające, że 1258 dysertacji wykonanych przez filozofów zawiera plagiat (bo w latach niepodległości Ukrainy obroniono 2515 dysertacji doktorskich z filozofii). Jeśli nie ma Pani dowodów, że 1258 dysertacji doktorskich z filozofii zawiera plagiat, wtedy słowa Pani o zdecydowanej większości są celowo nieprawdziwe. Nie wiem, w jak wielu przypadkach dysertacji doktorskich z filozofii według Pani potwierdzono, iż zawierają plagiat. Ale jeśli, powiedzmy, jest to nawet 20, 30 lub 40 dysertacji z plagiatem, to biorąc pod uwage 2515 obronionych dysertacji, nie jest to $50 \%$, ani nawet $10 \%$. W rzeczywistości uważam, że plagiat stanowiący jakikolwiek procent prac naukowych jest zawsze zjawiskiem haniebnym, z którym należy walczyć. Nie sądzę jednak, że wśród, powiedzmy, przedstawicieli Pani dziedziny - ekonomii - ten procent jest mniejszy niż w mojej dziedzinie - filozofii.

I wreszcie, znowu nie widzę w Pani komentarzach chęci uzasadnienia pierwszej Pani tezy, która wzbudziła moje zainteresowanie. Mam na uwadze Pani tezę o nienaukowości nauk humanistycznych jako takich. Mam wrażenie, że widzi Pani swoją rolę w naszej dyskusji w stosowaniu manipulacji i celowym obrażaniu przedstawicieli dziedziny, którą ja się zajmuję. Nie jest to rodzajem dyskusji, w której chcę uczestniczyć” (Kulik, 2019d). 
Komentując dyskusję, jeden z uczestników napisał: „Jestem zaskoczony ilością brudu, który w dyskusji na temat tego postu został wylany na przedstawicieli humanistyki... Co więcej, wylewają brud na przedstawicieli humanistyki, próbując udowodnić, że autor postu się myli, gdy wskazał, że są ludzie, którzy wylewają brud na humanistykę. To jakiś teatr absurdalny... każdy z ich komentarzy potwierdza poprawność jego postu" (Nesterenko, 2019).

Ten przykład jest szczególnie interesujący, ponieważ pokazuje dialog manipulatora $z$ naukowcem filozofem. W tej dyskusji ukraiński filozof Aleksander Kulik zademonstrował praktyczne zastosowanie technologii dyskusji zgodnie z zasadmi logicznego uzasadniania.

Ponieważ dialog prowadzony był między naukowcami, Kulik przeanalizował uwagi oponentki, celowo określając je odpowiednimi terminami naukowymi. Jednak interlokutorka nie wykazywała zamiaru prowadzenia merytorycznej dyskusji naukowej i cechował ją manipulacyjny styl rozmowy. Jej wypowiedzi były krótkie, sprawiały wrażenie haseł i nie zawierały żadnych konkretnych danych ani argumentów. Pomimo to odpowiedzi Kulika miały charakter naukowy i zawierały konkretne fakty i jasne argumenty.

Można podsumować, że oponentka demonstruje stereotypowe myślenie charakterystyczne dla osobowości dogmatycznej. Osoba myśląca dogmatycznie nie jest w stanie postrzegać informacji sprzecznej z jej własnymi przekonaniami - jej postawa nie poddaje się transformacji. I rzeczywiście, oponentka nie rozumie, „nie słyszy” logicznych dowodów i argumentów filozofa. Lub celowo nie przyjmuje argumentów swoich przeciwników w dyskusji, bo może jej świadomym celem jest wywołanie negatywnego hałasu informacyjnego i prowokacji w ukraińskiej społeczności naukowej.

\section{ZASTOSOWANIE LOGICZNEGO UZASADNIANIA W SPROSTOWANIU MITU}

Jako przykład zastosowania logicznego uzasadniania można przytoczyć manipulacje związane z zakazem wjazdu na terytorium Ukrainy, obowiązującym niektóre grupy Rosjan.

W kwietniu 2014 r. po aneksji Krymu ukraińska służba graniczna wprowadziła bardziej rygorystyczne zasady dla rosyjskich mężczyzn w wieku 
od 16 do 60 lat - zaczęto ich niezwykle szczegółowo pytać o cel podróży, co nie przyczyniło się jednak do zmniejszenia przepływu osób przez granicę państw. W 2015 r. Ukraina zakazała obywatelom rosyjskim wstępu na terytorium ukraińskie z paszportami cywilnymi - obecnie przekraczanie granicy ukraińsko-rosyjskiej zobowiązuje do przedstawienia paszportów zagranicznych. Pomimo to od października 2015 r. ukraińskie i rosyjskie linie lotnicze nie mają już prawa do bezpośrednich lotów między Ukrainą a Rosją. 26 listopada 2018 r. po agresji Federacji Rosyjskiej w Cieśninie Kerczeńskiej władze ukraińskie podjęły decyzję o wprowadzeniu w 10 obwodach stanu wojennego, który trwał od 26 listopada do 26 grudnia 2018 r. Z tego powodu od 30 listopada 2018 r. Ukraina zakazała wjazdu na terytorium ukraińskie rosyjskich mężczyzn w wieku od 16 do 60 lat. Zakaz ten obowiązuje również po zakończeniu stanu wojennego. Jego głównym celem jest uniemożliwienie Moskwie tworzenia „prywatnych armii” na swoim terytorium, jak to już wydarzyło się na Krymie i na terytorium obwodów donieckiego i ługańskiego.

Natychmiastowa reakcja Rosjan nie jest adekwatna - są obrażeni, że „Ukraińcy szaleją - oni od nas się odgradzają” (Hebel, 2018). Faktycznie osoby rosyjskojęzyczne poddane wpływom propagandy telewizji rosyjskiej są przekonane o poprawności i celowości rosyjskiej agresji w Ukrainie. Z punktu widzenia Rosjan kwestia zakazu wjazdu dla mężczyzn generuje tylko spojrzenie z jednej strony, tj. widzą tylko te efekty, które wpływają na ich życie codzienne, nie zauważając faktycznego problemu.

W trakcie dyskusji na ten temat według zasad logicznych argumentacji warto skierować również rozmowę na emocje - spróbować zapytać o uczucia rodzeństwo osób, które poniosły śmierć na skutek działań wojsk rosyjskich w trakcie wojny rosyjsko-ukraińskiej. Według stanu na sierpień 2017 r. zgodnie z informacją ONZ w czasie konfliktu od 14 kwietnia 2014 r. do 15 sierpnia 2017 r. zginęło co najmniej 2505 cywilów. Dodatkowo 298 cywilów zginęło w wyniku katastrofy samolotu MH17 17 lipca 2014 r. Całkowita liczba ofiar szacowana jest na 7000-9000 (Report on the human rights..., 2017). $\mathrm{Na}$ wykresie 1 przedstawiono udokumentowaną dokładną informację o ofiarach cywilnych wojny toczonej w Ukrainie. 
Wykres 1.

Ofiary cywilne konfliktów w Ukrainie (w okresie od 1 stycznia 2016 r. do 15 sierpnia 2017 r.)

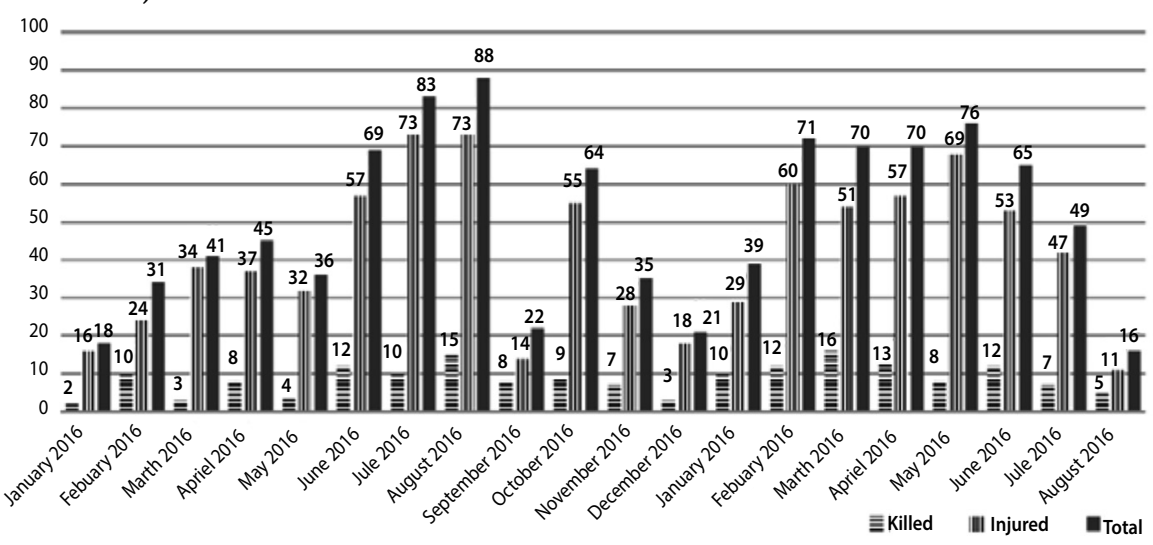

Źródło: Office of the United Nations High Commissioner for Human Rights (Report on the human rights..., 2017, s. 7).

Aby sprostować określony mit - czyli wywołać u oponenta rzetelnie uzasadnione przeświadczenie, iż proponowana teza jest prawdziwa - należy powołać się na fakty udokumentowane oraz naukowo uznane definicje i przedstawić je za pomocą logicznych, naukowych metod. W odpowiedzi na rosyjską propagandę i mitologizację, zgodnie z którą wojska rosyjskie nie biorą udziału w wydarzeniach na wschodzie Ukrainy - służby ukraińskie prowadzą działania mające na celu dokumentowanie nieprawdziwości tych informacji. Zwraca się uwagę m.in. na gromadzenie na stronie internetowej Ministerstwa Polityki Informacyjnej Ukrainy materiałów wideo i materiałów fotograficznych, potwierdzających obecność rosyjskich wojsk na terytorium ukraińskiego Donbasu (Proofs for Hague).

Ale jak podkreśla Zygmunt Ziembiński, należy też uważać na definicje perswazyjne, które polegają „na tym, że do definiensa definicji wprowadza się wyrażenie o charakterze oceniającym, nadając w ten sposób znaczenie oceniające również i wyrazowi definiowanemu” (Ziembiński, 2006, s. 212). Żadna ocena emocjonalna nie powinna mieścić się w definicjach naukowych i faktycznych, bo emocje te zawsze będą zwracać rozumowanie w stronę mitologizacji i stereotypizacji. Jako przykład można przytoczyć przekona- 
nie przedstawicieli Rosjan o tym, że Ukraina swoim wyjściem ze Związku Radzieckiego zdradziła „siostrę” Rosję. W tej wypowiedzi przytoczone jest nacechowane emocjonalnie pojęcie „zdrada”, którego stosowanie nie jest uczciwe w analizie historycznej. Poza zasadami demokracji, które przyznają narodom prawo na samostanowienia, wyjście Ukrainy z ZSRR miało podstawę prawną - było zgodne z art. 72 Konstytucji Związku Socjalistycznych Republik Radzieckich z 7 października 1977 r. (Konstitutsiya..., 1977), który głosił, że każda republika zachowuje wolne prawo wyjścia z ZSRR.

\section{WYNIKI}

Wysoki poziom kompetencji komunikacyjnej ma ta osoba, która nie absolutyzuje własnych ocen, uznając je za jedyne prawdziwe, a wszystkie inne oceny określając jako błędne. Właśnie uczciwość intelektualna polega na zawodowej umiejętności niepoddawania się emocjom i stosowania argumentacji logiczno-naukowej.

Podczas uzasadniania należy zawsze stosować postulat racji dostatecznej, według którego za prawdziwe uznaje się tylko takie treści, które można należycie uzasadnić.

Zastosowanie logicznego uzasadnienia w dyskusjach wymaga poszczególnej wiedzy. Chociaż nie gwarantuje niestety, że wreszcie uda się przekonać do swoich racji oponenta o mocnym światopoglądzie stereotypowym czy zmitologizowanym.

\section{Literatura}

Aronson, E. (2001). Człowiek - istota społeczna, Warszawa: Wydawnictwo Naukowe PWN, s. 481. ISBN 8301131586.

Nieznański, E. (2000). Logika: podstawy - język - uzasadnianie, Warszawa: Wydawnictwo C.H. Beck, s. 179. ISBN 8371107447.

Petty, R.E, Caccipo, J.T. (1986). The elaboration likelihood model of persuasion. Advances in experimental psychology, red. L. Berkowitz, Erlbaum, Hillsdale, NJ, s. 123-205. 


\section{Źródła internetowe}

Hebel, Ch. (2018). Einreiseverbot für Russen „Die Ukrainer sind verrückt, die sperren uns aus", 14.12.2018, http://www.spiegel.de/politik/ausland/russland-was-daseinreiseverbot-der-ukraine-fuer-die-menschen-bedeutet-a-1242198.html (dostęp: 1.12.2019).

Konstitutsiya (Osnovnoy Zakon) Soyuza Sovetskikh Sotsialisticheskikh Respublik. Prinyata na vneocherednoy sed'moy sessii Verkhovnogo Soveta SSSR devyatogo sozyva 7 oktyabrya $1977 \mathrm{~g}$. [Constitution (the Basic Law) of the Union of Soviet Socialist Republics adopted at the extraordinary seventh session of the Supreme Soviet of the USSR of the ninth convocation on October 7, 1977], http://www.hist.msu.ru/ ER/Etext/cnst1977.htm\#iii (w j. rosyjskim) (dostęp: 1.12.2019).

Kulik, A. (2019a). Otzhe, pani Svitlano, u vashiy stysliy vidpovidi..., Facebook, 30.11.2019, https://www.facebook.com/al.v.kulik/posts/2695508890540679?comment_id=2696817067076528\&reply_comment_id=2697200117038223 (w j. ukraińskim) (dostęp: 1.12.2019).

Kulik, A. (2019b). Pani Svitlana, Vy postavyly pytannya..., Facebook, 30.11.2019, https://www.facebook.com/al.v.kulik/posts/2695508890540679?comment_ id=2696817067076528\&reply_comment_id=2697008823724019 (wj.ukraińskim) (dostęp: 1.12.2019).

Kulik, A. (2019c). V Ukraine est' gruppa tovarishchey..., Facebook, https://www.facebook.com/al.v.kulik/posts/2695508890540679 (wj.rosyjskim) (dostęp: 29.11.2019).

Kulik, A. (2019d). Znovu u Vashiy vidpovidi manipulyatsiyi, Facebook, 30.11.2019, https://www.facebook.com/al.v.kulik/posts/2695508890540679?comment_ id=2696817067076528\&reply_comment_id=2697797030311865_(wj.ukraińskim) (dostęp: 1.12.2019).

Nesterenko, A. (2019). Porazhayus' tomu kolichestvu gryazi..., Facebook, https://www.facebook.com/al.v.kulik/posts/2695508890540679?comment_ $\mathrm{id}=2702225256535709$ ( $\mathrm{w}$ j. rosyjskim) (dostęp: 2.12.2019).

Proofs for Hague, Ministry of Information Policy of Ukraine, https://mip.gov.ua/en/ content/dokazi-dlya-gaagi.html (dostęp: 1.12.2019).

Report on the human rights situation in Ukraine 16 May to 15 August 2017. Office of the United Nations High Commissioner for Human Rights, https://reliefweb. int/sites/reliefweb.int/files/resources/UAReport19th_EN.pdf (dostęp: 1.12.2019).

Ziembiński, Z. (2006). Logika praktyczna, wyd. 26, Warszawa: Wydawnictwo Naukowe PWN, s. 283. ISBN 9788301119027. 